Roger Thornton

is a partner in the Commercial

Property Department at

Radcliffes. He qualified as a

solicitor in 1990 and has

extensive commercial property

experience. His particular

areas of expertise are property

development and investment,

and he has been involved in a

number of very large-scale

property development schemes

in the City of London. He also

handles large-scale property

investment work, including

buying and selling institutional portfolios.

Keywords:

shopping centre, lease, landlord, tenant, identity, clause

\section{Covenant quality}

Roger Thornton

Solicitor,

Radcliffes,

5 Great College Street,

Westminster,

London SW1P $3 \mathrm{SJ}$, UK

Tel: +44 (o) 2072227040

Fax: +44 (o) 2072226208

\title{
Shopping centre leases: Terms to seek and terms to avoid
}

Roger Thornton

Received (in revised form): 6th July, 2000

\begin{abstract}
This paper will look at some of the principal issues which are relevant to lettings of retail units, in particular retail units within shopping centres. It will look at a number of areas within the lease, such as user, alienation and rent review, to show how the perspective of the shopping-centre landlord and tenant differs from that of the ordinary commercial-office landlord and tenant. The shopping-centre landlord and tenant have an obvious community of interest. The success of the shopping centre, and its ability to attract shoppers and generate a lively active feel, are critical to both landlord and tenants. To achieve these, the landlord has to manage the centre actively, and secure the right mix of tenants in the right locations.
\end{abstract}

\section{THE IDENTITY OF THE PARTIES AND THE NEED FOR SECURITY}

The identity of the tenant is of critical importance to the shoppingcentre landlord. He will want to attract and retain tenants of good covenant strength to guarantee his income stream, as all landlords wish to do. However, he will also want to secure attractive 'anchor tenants' to draw other tenants in their wake, and also tenants who, together, provide the right retail mix.

Covenant strength is therefore not necessarily always the overriding consideration. Nevertheless, security for the covenant is often an issue, especially with occupiers of the smaller retail units or new niche retailers. Often an individual guarantee will be provided from the owner of the business or a rent deposit of say six or 12 months' rent will be available. To be avoided where possible are guarantees from overseas parent companies, which can be difficult and expensive to enforce.

In assessing the covenant strength of the tenant, the shoppingcentre landlord (like all commercial landlords) also has to have regard to the Landlord and Tenant (Covenants) Act 1995 ('the 1995 Act'). Tenants of leases granted after 1st January, 1996 are now not automatically liable after they assign their lease. They may be required to provide a limited guarantee for their immediate successor (an authorised guarantee agreement or AGA), but otherwise they are released from further liabilities on assignment of the lease.

There are one or two practical points resulting from the 1995 Act for the shopping-centre landlord/manager: 


\section{The impact of the 1995 Act}

\section{Flexibility versus certainty}

\section{Does the break clause work?}

Firstly, the retail tenant may well be a shell company, and the landlord's true protection arises from the guarantor. It is not clear from the Act whether a tenant's guarantor may also guarantee that tenant's obligations under an AGA. The only fail-safe way to protect against this potential risk is to provide that the guarantor is a joint tenant under the lease (whether this is commercially acceptable to the tenant in the context of a particular deal is, of course, another consideration).

Secondly, the Act provides (and this is in relation to all leases, not merely those granted on or after 1st January, 1996) that any arrears of rent and service charges to be claimed by the landlord from former tenants or their guarantors must be claimed within six months of the date on which the outstanding sums became due. Shopping-centre managers must therefore ensure that they have efficient procedures in place so they do not lose the right to claim arrears by claiming them too late or in the wrong way. They will therefore need to keep accurate records of addresses and details of former tenants and act swiftly.

\section{TERM AND BREAK CLAUSES}

Flexibility is the current buzzword for all leases, but especially retail leases. There is no longer a rule of thumb as to lease length. The recent proposed change to the accounting standard for commercial leases is likely to be implemented, and will have a significant effect on the balance sheet of retailers, especially multiple/chain retailers. Essentially, the change will mean that the full rental liability of a tenant for the entire lease term will be calculated and shown on the tenant's annual balance sheet. This will have a significant effect on the tenant's gearing ratios, and tenants may seek to mitigate the effect of this change by seeking shorter lease terms or break clauses.

However, retail landlords will want to retain longer leases and avoid break clauses so as to reduce the potential significant costs of voids and reletting. Landlords will always want a longer term for anchor stores.

If a break clause is accepted, tenants should always seek to avoid break clauses in their favour which are expressed to be conditional upon, for example, 'the observance and performance of the covenants on its parts contained in the lease'. Such conditions are interpreted strictly, and failure to comply in full will cause the tenant to lose the right to break. For example, in Osborne Assets Ltd $v$ Britannia Life $L t d^{1}$ a lease contained such a conditional break clause. The tenant's obligations included the requirement that the premises be repainted with three coats of paint. Only two coats were given - and the tenant lost the right to break!

The lease should set out clearly and unambiguously the steps that need to be taken for the exercise of a break right. The right will usually be triggered by the service of a notice. Landlords and tenants receiving an unwelcome break notice should always check whether it is valid and has been validly served. A House of Lords 
Security of tenure

\section{Turnover rents}

Rent reviews decision in 1997 - Mannai Investment Co Ltd v Eagle Star Life Assurance Co $L t d^{2}$ — introduced a degree of flexibility in this respect. Before this case, the rule for break notices had generally been that the notice would be ineffective if it referred to an incorrect date. In Mannai the tenants mistakenly served a notice to determine, which was expressed to take effect one day earlier than required by the terms of the lease. The court ruled that the contractual break notice was effective even though it specified an incorrect date. This was on the basis that a reasonable recipient would understand what the break notice was intended to achieve.

The landlord will need to consider whether or not he wishes to contract the lease out of the security of tenure afforded to business tenants by the Landlord and Tenant Act 1954. If the lease is not contracted out, the tenant will have the statutory right to remain at the premises after the end of the contractual term. The same issues apply to both commercial-office and retail landlords. It is a question in each case of negotiation between the parties.

\section{RENT AND RENT REVIEW}

The amount of the initial rent will usually be ascertained before lawyers are instructed. It is not uncommon for leases of shopping centres and factory outlets to link rents to the tenant's turnover. If this is done, it is generally the case that a basic rent is reserved and an additional variable rent is also payable linked to the turnover of the tenant's business at the premises. One advantage of this is that the landlord will be financially interested in the success of the tenant's business, and thus motivated to encourage that success by proper and efficient maintenance and running of the shopping centre.

The lease will need to provide a clear-cut and unambiguous definition of turnover; how it should be ascertained; the rights of the landlord to inspect the tenant's books; and so on. For his part, the tenant may prefer to see the rent geared not to pure turnover but to actual profit achieved; however, this may be of concern to the landlord as the level of the rent - or at least a part of it would then become more dependent on the business efficiency of the tenant. Thought must in any event be given by both parties to the detail of what is and is not to be taken into account in the definition of turnover. For example, recent press reports have highlighted that the increase in online sales may well make the issue of returned goods more relevant in this respect. A landlord of a turnover rent lease should ensure that goods ordered online or otherwise from the unit in question but returned to that unit should not be deducted from the turnover figure for those premises.

Turning briefly to rent review, several parts of this paper will be referring to the effect of particular provisions and restrictions in the lease on the rent achievable at review. The retail landlord will often seek to impose restrictions on the user and alienation to secure the right tenant mix for the centre (discussed below). These will 
Freedom to assign vesus control of tenant mix inevitably have a depressing effect at review, and it is a fine balance for the landlord to achieve between control and rent review. Some landlords may manage to incorporate a specific 'disregard' of the more onerous controls in the lease for rent review purposes, but a well-advised tenant will resist this.

As a final point under rent it should be noted that retail landlords always seek to define all sums due under the lease as 'rent'. This allows them to distrain on goods in the premises for arrears. Distraint, while often of limited use as a remedy under office leases, can be effective for retail premises where goods can be seized and sold. It is interesting to note the potential effects of the new human rights legislation on this remedy.

\section{TENANTS' COVENANTS: ALIENATION}

The shopping-centre landlord will want to control the tenant's ability to transfer the lease. In addition to the usual landlord's concern that any purchaser is of good enough covenant strength to be able to pay the rent and comply with the tenants' obligations in the lease, the retail landlord will also want to ensure that a satisfactory mix of retail tenants is maintained. The tenant, on the other hand, while happy that other retail tenants are bound by such restrictions in the interests of managing the mix in a centre, will want to avoid such restrictive provisions himself and will want flexibility in terms of sub-letting, sharing occupation, granting concessions or selling his lease.

If the lease is silent, a tenant has an absolute right to assign. Commercial leases have traditionally contained qualified restrictions upon assignment, along the lines that 'the tenant cannot assign without the consent of the landlord, such consent not to be unreasonably withheld'. Even if the words 'not to be unreasonably withheld' are omitted, they are nevertheless imposed by statute (Section 19(1) Landlord and Tenants Act 1927 provides that where a landlord's consent is required to assignment or sub-letting, that consent cannot be unreasonably withheld, regardless of what the lease itself says).

What is meant by 'reasonableness'? While the courts have given some guidance as to the basic principles to be taken into account (see, for example, International Drilling Fluids v Louisville Investments (Uxbridge ${ }^{3}$ ), there are no hard-and-fast rules and one must look at the circumstances of each case. Generally, however, the landlord must not seek a 'collateral advantage' - for example, a refusal by a landlord in an attempt to persuade the tenant to surrender his lease was held to be unreasonable (Strandley Investments Limited v Mount Edan Estates ${ }^{4}$ ). It has also been held in a recent case that a landlord was unreasonable in refusing consent with a view to enhancing or avoiding comparisons which might be detrimental to future rent levels of its adjoining shops (Norwich Union Insurance Society v Shopmoor Limited ${ }^{5}$ ).

In the midst of this uncertainty, the Landlord and Tenant 
Good estate management?

Flexibility of user versus control of tenant mix
(Covenants) Act gives a big help to shopping-centre landlords. The Act permits the landlord in advance to agree with the tenant conditions which must be satisfied before an assignment will be permitted. These conditions must be complied with even if they are 'unreasonable'.

The landlord therefore has the ability to negotiate up front any restrictions on assignment he may wish to impose; for example, requiring any assignee to be acceptable to the landlord from a management/tenant mix point of view (and allowing the landlord a discretion in determining this). However, he must weigh this in the balance with the fact that any conditions which go further than the basic 'reasonableness' test are likely to have an adverse effect on rent review. The landlord must, at all costs, avoid inserting a lengthy blanket set of standard conditions on assignment.

It should be noted that the guidelines and case law interpreting the concept of 'reasonableness' in relation to assignment apply equally in relation to consents to sub-let, carrying out alterations or change of use.

It is worth mentioning one recent case which helps illustrate these issues. In Moss Bros Group plc v CSC Properties Limited, ${ }^{6}$ the clothes retailer in a major shopping mall sought consent to assign its lease to an electronic games retailer and also to change the use permitted by the lease. The lease provided that any assignment needed prior written consent of the landlord, not to be unreasonably withheld; change of use also required approval, which would not be unreasonably withheld if in the reasonable opinion of the landlord such approval would be "consistent with the principles of good estate management, having regard in particular to the distribution of the retail trades in the [centre]'. The landlord refused consent, stating that a change would be inconsistent with tenant mix policy. The court accepted that consent had been reasonably withheld.

\section{USE OF THE PREMISES}

Again, to secure tenant mix the landlord will want to control closely any changes in the permitted use. The tenant will want to ensure that the use permitted by the lease is broad enough to encompass everything that he - and perhaps his successor - will want to sell; the landlord, on the other hand, will want to retain sufficient control over retail use to avoid competing and undesirable uses within the shopping mall and to maintain standards, while at the same time avoiding too restrictive a regime which would reduce the rent achievable on a rent review.

It is not unusual to see a regime along the lines that the permitted use is 'use as a retail shop for such purpose as the landlord may from time to time approve, such approval not to be unreasonably withheld'.

One point for the tenant here - unlike consents in relation to assignment and sub-letting, there is no statutory intervention which 


\section{Competing uses}

\section{Trading hours}

Keep open covenants provides that consent to a change of use cannot be 'unreasonably withheld or delayed'. The words must therefore be specifically inserted.

A well-advised landlord may want to be a little more specific, for example, by adding that consent can be refused if the proposed use conflicts with principles of good estate management, is inconsistent with a high-class shopping centre or conflicts with any covenant or non-competition agreement between the landlord and other occupiers or tenants at the centre.

Tenants, again while resisting such controls themselves, will be concerned to ensure that there are no competing or inappropriate uses in the vicinity of their retail units. In Romulus Trading Co. Ltd \& Another $v$ Comet Properties $\mathrm{Ltd}^{7}{ }^{7}$ the landlord owned a substantial block of property. One unit in the block was underlet to a bank. The landlord subsequently underlet another unit, again for use as a bank-related business. The first tenant issued proceedings against the landlord, claiming that by letting adjoining premises for a similar use he was in breach of his express obligation contained in the lease to 'administer the building and the common parts ... in accordance with the principles of good estate management'. It was held that this was not so. An obligation to administer in accordance with principles of good estate management could not be strained to include consideration of letting policy or relaxation of user covenants. If the premises were let for a particular trade there was nothing to prevent the landlord from leasing an adjoining shop for the same purpose. It is difficult to know how far this case can be applied. For example, would the court have come to the same view if it was a shopping centre rather than an office block incorporating some ground-floor retail units.

Returning to the landlord, in addition to achieving and maintaining a good retail mix, he may also want to impose other obligations and restrictions as to use. The landlord of a sophisticated shopping mall will want to create an atmosphere of a busy centre, attracting both shoppers and potential tenants and with no voids, particularly in relation to anchor stores. Such a landlord must cater for this in the lease. He should consider imposing obligations as to minimum (and maximum) trading hours, requiring the tenant to keep open for trading during specified trading hours (subject, perhaps, to a caveat that closure for reasonable periods, for example, for shop fitting, might be permitted). There are two issues in particular to be borne in mind in relation to such a restriction - enforceability and, once again, rent review.

Keep-open covenants of this nature were dragged into the limelight by Co-operative Insurance Society Limited v Argyll Stores (Holdings) Limited. ${ }^{8}$ Argyll were tenants of a large anchor unit in the Hillsborough shopping centre, the permitted use being as a supermarket. The tenants covenanted to keep the premises open during business hours and to keep the display windows properly 
Enforcing keep open

Appearance/Shop fronts dressed. However, they decided to close the supermarket and informed the landlord of this, subsequently closing the store and stripping out the fittings. The landlord sued for specific performance and damages. The Court of Appeal ordered Argyll to re-open, but the House of Lords reversed this decision and refused to grant the landlord an order for specific performance. The House of Lords stated that there was an established principle that the courts will not order a party to run a business, and the courts should apply this in all but the most exceptional circumstances. Damages only were therefore available.

In the absence of the remedy of specific performance, is there anything a landlord can do to give teeth to a keep-open covenant, while also avoiding a claim for unliquidated damages which can be dauntingly expensive to pursue? One solution which has been suggested is to incorporate a specified liquidated damages provision in the keep-open covenant, for example, by providing a specified daily rate for damages in the event of breach; this would be a comparatively inexpensive and easily quantified remedy. However, it would be important to ensure that the specified amounts were a genuine pre-estimate of damages, otherwise such a provision might be struck down as a penalty. Another remedy is the insertion of a break clause in favour of the landlord in the event of a breach of a keep-open covenant. Again, however, the landlord must have an eye on the fact that a keep-open covenant can have a depressing effect on rent at a review.

In addition to keeping open, the landlord might want to maintain the appearance of the shopfront. In Charville Estates Limited v Unipart Group Limited, ${ }^{9}$ a lease of a unit in a shopping centre contained a covenant to maintain a window display at all times. The tenant failed to do so, and indeed vacated the premises, although still paying the rent. The landlord entered the premises to rectify the situation without informing the tenant. The tenant tried to argue that the re-entry constituted surrender by operation of law so that rent was no longer payable. The court disagreed, partly because entry had been of a very limited nature; however, landlords should ensure that they exercise caution before entering the premises in this way, and in particular should notify the tenant that they are doing so only for a very limited purpose.

\section{THE LANDLORD'S OBLIGATIONS}

The tenant will want to ensure that the shopping centre is maintained to a certain standard and insured, and that all necessary rights and facilities are provided and maintained. These would include means of access, car-parking facilities, lifts and escalators, toilet facilities, the provision of lighting, heating, cleaning, air conditioning, refuse collection, security, traffic control systems - the list is potentially endless. Tenants of more sophisticated malls will also want more. These requirements should all be specified in the lease.

The landlord may want to include other services which he may 


\section{Landlord's management obligations}

\section{What should be included?}

from time to time consider appropriate 'having regard to principles of good estate management'. A well-advised landlord will also want to ensure that the obligation to provide services is not absolute for example, he may be prevented from doing so due to circumstances beyond his control. He may also want prior notice of any defects or failures.

One case is worth mentioning in the context of a landlord's management obligations. The liability of the landlord to a tenant in relation to disruptive behaviour within a shopping mall was considered in Chartered Trust plc v Davies. ${ }^{10}$ One of the units in the mall was let to a Mr Davies for use as a specialist shop selling presents and executive toys. An adjoining unit was let to a pawnbroker, and the manner in which the pawnbroker's business was conducted was claimed to have had a severe adverse effect on Mr Davies's enterprise. Among other complaints, entry into the pawnbroker's shop was restricted to one customer at a time so that other customers - and there were many - hovered outside, deterring passing trade. Mr Davies withheld rent and disclaimed the lease, contending that the landlords had derogated from their grant by failing to control the nuisance caused by the pawnbroker. Were the landlords responsible? The Court of Appeal held that they were. The court placed great emphasis on the fact that the shop was part of a shopping mall where the landlord retained a considerable managerial role. In order to succeed in the claim against the landlord, the tenant had to show that the landlord had a duty to act, and 'where a landlord is granting leases in his shopping mall, over which he has maintained control and charged a service charge therefor, it is simply no answer to say that the tenant's sole protection is his own ability and willingness to bring an individual action ... the duty to act should lie with the landlord'. In this case, the landlords could have acted by enforcing a covenant against causing a nuisance contained in the pawnbroker's lease or by establishing and enforcing regulations to ensure that the mall was kept clear; but they did nothing. The brief and practical conclusion for the landlord must be that the assumption of a managerial role within a tightly controlled development such as a shopping centre increases the need to be proactive in controlling nuisances and disruptive behaviour.

\section{SERVICE CHARGES}

The landlord will want to recover the costs he incurs in running, managing, maintaining and insuring the shopping centre by way of a service charge. Each tenant's proportion is often calculated by reference to the ratio of the area of each individual unit to the rest of the lettable areas within the centre. If there is any possibility of these changing, the landlord should reserve the right to amend the service charge percentage. The landlord should allow/envisage the expansion of the centre. Tenants may not object as this should reduce their contributions, although this will depend on the extent 
Recovering arrears following landlord's error and nature of the expansion. The tenants will want to ensure that the service charge does not oblige them to fund voids, expansion, construction costs and promotion or advertising costs. The management costs should also be limited.

A fairly recent case (Universities Superannuation Scheme Limited $v$ Marks \& Spencer plc ${ }^{11}$ ) contains some good news for landlords in relation to service charges. The service charge payable by the tenant under a lease was calculated by reference to the rateable value of the tenants' premises as against the rateable value of the whole shopping centre in question. The landlords miscalculated their service charge percentages and sought to recover the shortfall from the tenants several years after the event. The issue before the court was whether the tenant, by paying the incorrect amount showing on the landlord's service charge certificate, had fulfilled its contractual obligation in the lease to pay the landlord service charges for the periods in question. The Court of Appeal - perhaps rather surprisingly - held that they had not, despite the time lag. The service charge provisions in the lease had to be interpreted so as to fulfil, rather than defeat, their purpose. The clear purpose was to provide the landlord with a means of maintaining the shopping centre; the payment of the lesser sums by the tenant was not full performance of its contractual duty.

\section{THIRD-PARTY RIGHTS}

Finally, just a mention of the impact of the new legislation regarding third-party rights. It provides that in certain circumstances third parties may be able to enforce the benefit of covenants in contracts (eg leases) to which they are not a party. It is possible, therefore, that other tenants within a shopping centre may be able to enforce, for example, keep-open covenants in anchor store leases for their own benefit. The Act can be expressly excluded from contracts, and landlords will need to think very carefully about its impact on their standard shopping-centre leases. It would seem prudent for landlords to exclude this legislation.

\footnotetext{
References

1. Unreported, 1997.

2. [1997] 1 EGLR 57.

3. [1986].

4. [1997] EGCS 175.

5. [1999] 1 WLR 531.

6. [1999] EGCS 47.

7. [1996] 48 EG $157(\mathrm{QBD})$.

8. [1996] 3W/LR/HL.

9. [1997] EGCS 36.

10. [1997] 49E G 135(CA).

11. [1998] EGLR.
} 